\title{
建物や捕捉エなどの影響を考慮した 津波漂流物解析モデルの開発
}

\author{
野島 和也 ${ }^{1}$ - 桜庭 雅明 2 - 小園 裕司 $^{3}$ \\ 1正会員 日本工営株式会社中央研究所（テ300-1259 茨城県つくば市稲荷原2304） \\ E-mail: nojima-kz@n-koei.jp \\ 2正会員 日本工営株式会社中央研究所（テ300-1259 茨城県つくば市稲荷原2304） \\ E-mail: sakuraba-ms@n-koei.jp \\ 3 正会員 日本工営株式会社中央研究所（テ300-1259 茨城県つくば市稲荷原2304） \\ E-mail: kozono-yj@n-koei.jp
}

\begin{abstract}
2011年の東北地方太平洋沖地震では, 津波に伴い多くの種類の漂流物が発生した。漂流物は衝突や滞留 に伴う被害拡大の要因となり，津波の浸水範囲と合わせて被害の推定が必要である。本研究では，津波の 浸水予測を行う方法を拡張して複数の種類の漂流物の移動を推定する数值シミュレーションモデルを開発 した. 本研究で開発したモデルは, 様々な状況における力学的な挙動を従来の津波シミュレーションを拡 張したモデルとして考慮が可能なものとなっている. 適用例として, 建物周辺の漂流物の挙動解析を行い, 既往の実験結果の整合性を評価した。また，多種多数の漂流物を対象とした遡上域，建物および津波捕捉 工などの影響を含めた解析を行った。これらの結果より, 様々な物理機構を踏まえた漂流物挙動が従来の 津波解析の拡張として算定できるものとした.
\end{abstract}

Key Words : 2D tsunami simulation, tsunami drift, distinct element method

\section{1. はじめに}

2011年の東北地方太平洋沖地震津波では津波による浸 水被害だけでなく，自動車，船舶およびコンテナなどが 陸域で漂流物となって移動，衝突し，これに伴う被害が 広範囲で発生した。この津波による各地での被害は津波 の浸水だけでなく, 衝突に伴う構造物の損壊, がれきの 発生や油の流出による火災・延焼および船舶の座礁など 様々な2次的な被害の発生が見られた。このような被害 を鑑み，津波被害想定および対策を検討するにあたって は, 漂流物の種別を踏まえた浸水域での移動・滞留状況 を推定することが重要である. 津波漂流物被害の予測を 行うにあたり, 最近では関連のガイドラインクが公表さ れるようになり，具体的な漂流物被害の推定および対策 指針が示されている．また，漂流物の移動を予測する方 法として, 従来の2次元の津波シミュレーションの結果 を用いて漂流物を質点系の運動として仮定する方法2,3, 同様の結果から漂流物を剛体として扱い運動過程を表現 する方法4,5)，また流体運動を含めて3次元解析で行う方 法のなどが提案されている. 2次元計算結果から漂流物の 運動を解析する方法は広範囲における漂流物の移動過程 を表現する方法として適しており，実務的に有力な方法
であるが，水域・陸域での摩擦を考慮した移動や建物一 の衝突に対しては近似的な取り扱いとなっている. 一方, 3次元解析による方法は, 漂流物の形状や様々な物理過 程を厳密に取り扱うことが可能であるが，計算量が膨大 になるために，計算範囲の設定や計算機資源に対して制 約があるのが現状である. 津波に伴う漂流物挙動を推定 するためには，できるだけ広い対象範囲で様々な種類， 形状を表現しつつ, 構造物や漂流物の物理的な条件を踏 まえることが望ましい．

本研究では, 従来の2次元の津波シミュレーションモ デルを拡張して, 構造物等への衝突および遡上域での摩 擦の影響を表現できるモデルを開発した. 本モデルは, 津波に関する流体運動と漂流物運動の相互干渉を考慮で き，地形や構造物の影響による衝突，座礁の影響が考慮 できる．漂流物は個別要素による集合として表現してい るため，様々な大きさや重量を設定できる，また，従来 から用いられる2次元の津波シミュレーションのデータ を活用できる. 本研究で開発したモデルを既往の実験検 討との比較を行いモデルの妥当性を示した. 更に, 応用 例として, 多種・多数の漂流物に対し構造物や津波捕捉 工などの影響を踏まえた解析を行い，提案したモデルの 適用性を考察した。 


\section{2. 計算手法}

\section{(1) 津波シミュレーション}

津波の伝播および浸水の数值シミュレーションには Leap-Frog法に基づく差分法を適用した7). なお，本研究 では，津波と漂流物の相互干涉効果を取り入れるために， 基礎方程式の浅水長波方程式の運動方程式に漂流物から 受ける流体力項（式(2),(3)の右辺第3項）を考慮した.

$$
\frac{\partial \eta}{\partial t}+\frac{\partial M}{\partial x}+\frac{\partial N}{\partial y}=0
$$

$\frac{\partial M}{\partial t}+\frac{\partial}{\partial x}\left(\frac{M^{2}}{D}\right)+\frac{\partial}{\partial y}\left(\frac{M N}{D}\right)=-g D \frac{\partial \eta}{\partial x}-F_{\tau_{b x}}-F_{x}$

$\frac{\partial N}{\partial t}+\frac{\partial}{\partial x}\left(\frac{M N}{D}\right)+\frac{\partial}{\partial y}\left(\frac{N^{2}}{D}\right)=-g D \frac{\partial \eta}{\partial y}-F_{\tau_{b y}}-F_{y}$

ここに， $\eta, M, N, D$ は，それぞれ，水位， $\mathrm{x}$ 方向流 速, y方向流速, 全水深であり, $F_{\tau_{b x}}, F_{\tau_{b y}}$ は底面摩擦, $F_{x}, F_{y}$ は，漂流物から受ける力を示寸. 流体力項は計算 格子のひとつのセルに注目すると次の様に表すことがで きる.

$$
F_{x}^{\text {cell }}=\sum_{k=1}^{N_{p}^{\text {cell }}} w_{k} F_{f x}^{k} / d A, \quad F_{y}^{\text {cell }}=\sum_{k=1}^{N_{p}^{\text {cell }}} w_{k} F_{f y}^{k} / d A
$$

ここに, $N_{p}^{\text {cell }}$ はセル近傍にある漂流物要素の数, $F_{f x}^{k}$, $F_{f y}^{k}$ は後述する漂流物が流体から受ける力のx軸, $\mathrm{y}$ 軸成 分, $w_{k}$ は漂流物の寄与度を表す重み関数, $d A$ は計算セル の面積である.

$\left\{\begin{array}{cc}w_{k}=\frac{d x-|\xi|}{d x} \cdot \frac{d y-|\zeta|}{d y}: & |\xi| \leq d x \text { かつ }|\zeta| \leq d y \\ w_{k}=0 & :|\xi|>d x \text { または }|\zeta|>d y\end{array}\right.$

ここに，乡，ろはセル中心を原点とした漂流物要素の座標, $d x, d y$ はセルの大きさを示す. 図-1に示すような漂流物 要素 $k=1$ では $w_{k}$ は1.0となり, 漂流物要素からの力は 全てセル $(i, j)$ にかかる. 隣要するセル $(i, j+1)$ との中 間に位置する $k=2 て ゙ は w_{k}$ は0.5となる，また，この場 合は $N_{p}^{\text {cell }}$ は6となる.

\section{(2) 漂流物の挙動解析}

漂流物は円柱状の複数の漂流物要素の集合として表現 し（図-2参照），個別要素法により挙動を計算した。個 別要素は法線・接線方向に対しバネ・ダッシュポッドモ デルとして漂流物の弾性変形を考慮した．鉛直方向の力 は浮力のみ考慮し，鉛直移動も可能とした。漂流物の影 響により生じる流体力を浅水流モデルの運動方程式に反 力として反映し，流体と漂流物の相互干涉効果を取り入 れた.

\section{a) 運動方程式}

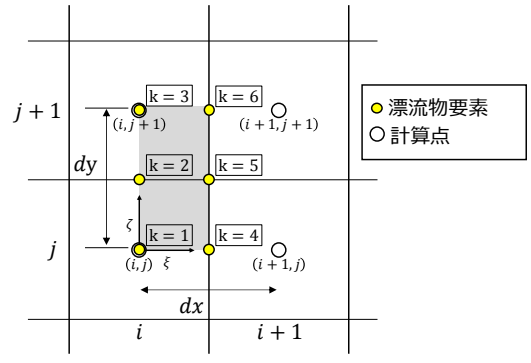

図-1 漂流物と計算点の位置関係

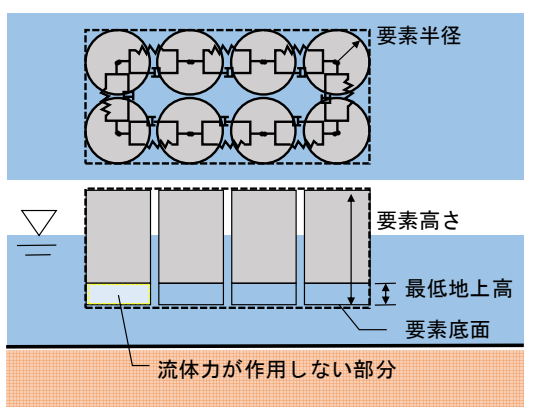

図-2 漂流物モデルの概念図および個別要素の定義

個々の漂流物要素の挙動は以下に示す運動方程式を用 いて予測する.

$$
\begin{aligned}
& m \frac{\partial u_{t}}{\partial t}=F_{f x}+F_{h x}+F_{b x}+F_{s x}+F_{c x}+F_{r x} \\
& m \frac{\partial v_{t}}{\partial t}=F_{f y}+F_{h y}+F_{b y}+F_{s y}+F_{c y}+F_{r y}
\end{aligned}
$$

ここに， $m$ は各要素の質量， $u_{t}, v_{t}$ は漂流物のx軸方向， 軸方向の速度, $F_{f x}, F_{f y}$ は津波挙動により生じる流体力, $F_{h x}, F_{h y}$ は静水圧により流体から受ける力, $F_{b x}, F_{b y}$ は 摩擦力のx軸, 軸成分, $F_{s x}, F_{s y}$ は地形勾配と重力により 受ける力, $F_{c x}, F_{c y}$ は接触力, $F_{r x}, F_{r y}$ は漂流物内部のせ 儿断変形による力である.

\section{b) 津波挙動による流体力}

動水により漂流物が津波から受ける力（流体力）は， Morison式で表現し，以下のようになる.

$$
\begin{aligned}
& F_{f x}=\frac{1}{2} \rho_{f} C_{d} A_{x}\left(u-u_{t}\right) \cdot\left|u-u_{t}\right| \\
& F_{f y}=\frac{1}{2} \rho_{f} C_{d} A_{y}\left(v-v_{t}\right) \cdot\left|v-v_{t}\right|
\end{aligned}
$$

ここに, $C_{d}$ は抗力係数, $A_{x} A_{y}$ は漂流物要素の水没部分 のx軸方向，y軸方向の投影面積， $u, v お よ ひ ゙ ~ u_{t}, v_{t}$ はそれ ぞれ，流体の流速のx軸，y軸成分，および，漂流物要素 の移動速度のx軸, $\mathrm{y}$ 軸成分, $\rho_{f}$ は流体の密度を示す.

\section{c) 静水圧}

流体力は，流体と漂流物各要素の相対速度により力が 表現されるため, 漂流物が静止している状態では力が生 じないことになる. 長さを持つ漂流物が水位差のある場 所で静水圧を受ける場合，その差により力が生じる. 静 水圧は漂流物の表面上に内向き法線方向に働くものとし， 静水圧により漂流物要素に働く力は下記の式より求める. 


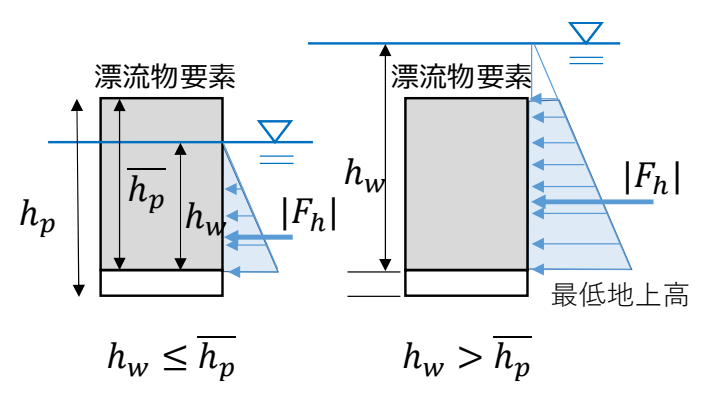

図-3 漂流物要素の鉛直位置と静水圧による力
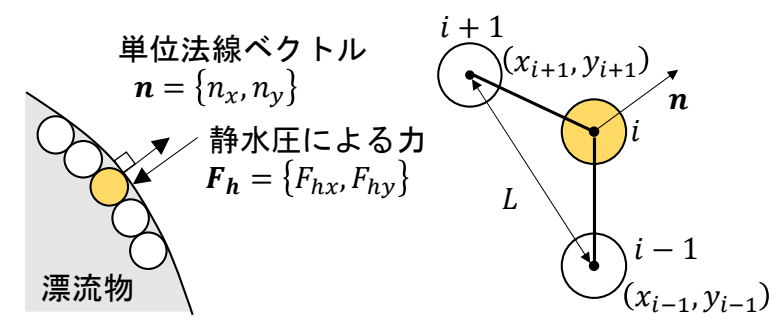

図-4 静水圧の作用方向と外向き単位法線ベクトル
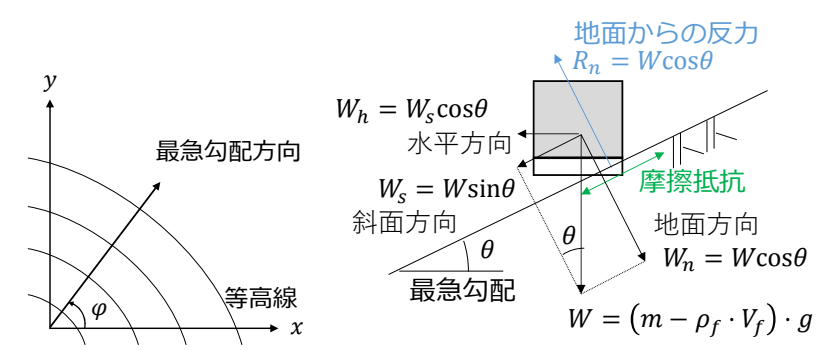

図-5 斜面上の漂流物に働く力

$$
\begin{aligned}
& \left\{\begin{array}{lll}
\boldsymbol{F}_{h}=\frac{1}{2} \rho_{f} g h_{w} A \cdot \boldsymbol{n} & : & h_{w} \leq \overline{h_{p}} \\
\boldsymbol{F}_{h}=\frac{1}{2} \rho_{f} g\left(2 h_{w}-h_{p}\right) A \cdot \boldsymbol{n} & : & h_{w}>\overline{h_{p}}
\end{array}\right. \\
& \boldsymbol{F}_{\boldsymbol{h}}=\left\{F_{h x}, F_{h y}\right\}, \quad \boldsymbol{n}=\left\{n_{x}, n_{y}\right\}
\end{aligned}
$$

ここに, $\boldsymbol{F}_{\boldsymbol{h}}$ は静水圧による流体力べクトル， $\boldsymbol{n}$ は外向き 法線ベクトル, $h_{w}$ は水面から漂流物要素の最低地上高 を除く底面までの高さ， $\overline{h_{p}}$ は最低地上高を除く要素の 高さである (図-3 参照)。最低地上高は，車両のタイヤ や貯蔵タンクの脚などの浮力が働かない部分の高さであ る. 単位法線ベクトルの成分は図-4 に示寸関係を用い て次式より求めることができる.

$$
n_{x}=\frac{y_{i+1}-y_{i-1}}{L}, n_{y}=-\frac{x_{i+1}-x_{i-1}}{L}
$$

\section{d) 浮力}

漂流物の鉛直位置は漂流物の重心における漂流物総重 量と全漂流物要素の浮力の総和のつり合から求める. 各 漂流物要素に働く浮力は, 次式で計算する.

$$
\left\{\begin{array}{cll}
F_{v}=\rho_{f} g h_{w} \pi r^{2} & : & h_{w} \leq \overline{h_{p}} \\
F_{v}=\rho_{f} g \overline{h_{p}} \pi r^{2} & : & h_{w}>\overline{h_{p}}
\end{array}\right.
$$

ここに, $r$ は要素の半径, $h_{w}, \overline{h_{p}}$ は前項で示寸通りであ る.

\section{e) 地形勾配により生じるカ}

傾斜のある地面の上では，図-5 に示すように漂流物 には斜面の接線方向成分の力 $W_{s}$ が生じる. 接線方向に 働く力の水平方向成分を求めて, $\mathrm{x}$ 軸方向と $\mathrm{y}$ 軸方向に 分解することで，地形勾配により漂流物に働く力とする. 地形勾配により漂流物要素に働く力の $\mathrm{x}$ 軸方向および $\mathrm{y}$ 軸方向の成分は, 次の式より求められる.

$$
F_{s x}=-W_{h} \cdot \cos \varphi, \quad F_{s y}=-W_{h} \cdot \sin \varphi
$$

ここで， $\varphi$ は軸と最急勾配方向とのな寸角度である.

\section{f) 地面との摩擦力}

底面摩擦力は図-5の地面に平行に働く力である. 摩擦 力は漂流物の移動状況により動摩擦力と静止摩擦力に分 けて考える. 静止摩擦力は, 次の式で求める.

$$
\left\{\begin{array}{cll}
\boldsymbol{F}_{b}=-\frac{\boldsymbol{F}}{|F|} \mu_{s} W_{n} & : & \left|F_{b}\right|<|F| \\
\boldsymbol{F}_{b}=-\boldsymbol{F} & : & \left|F_{b}\right| \geq|F|
\end{array}\right.
$$

ここに, $\mu_{s}$ は静止摩擦係数, $\boldsymbol{F}$ は静止摩擦力を除く漂流 物要素に作用する外力の総和である. 静止摩擦力は $\boldsymbol{F}$ と 逆向きに働き, また, $|F|$ よりも大きくならないものと 寸る. 動摩擦力は, 次式より求める.

$$
F_{b x}=-\frac{u_{t}}{\left|u_{t}\right|} \mu_{d} W_{n}, \quad F_{b y}=-\frac{v_{t}}{\left|v_{t}\right|} \mu_{d} W_{n}
$$

ここに, $\mu_{d}$ は動摩擦係数であり, 動摩擦力は要素の移 動方向に対して逆向きに働く.

\section{g) 漂流物要素間力}

漂流物の個別要素の要素間力の算出はバネとダッシュ ポットのモデル(図-2 参照)で表現し, 軸方向に働く力 は次式のとおりバネ力 $F_{e}$ とダッシュポットによる力 $F_{d}$ の総和になる.

$$
\begin{aligned}
& F_{c x}=-\sum\left(F_{e}+F_{d}\right) \cdot\left(x_{j}-x_{i}\right) / L_{i j} \\
& F_{c y}=-\sum\left(F_{e}+F_{d}\right) \cdot\left(y_{j}-y_{i}\right) / L_{i j}
\end{aligned}
$$

バネ力 $F_{e}$ おびダッシュポットによる力 $F_{d}$ は，要素間 の距離と相対速度を用いて，次式により算出する.

$$
\begin{gathered}
F_{e}^{t+\Delta t}=k \cdot\left(L_{i j}^{0}-L_{i j}^{t}\right) \\
F_{d}^{t+\Delta t}=c \cdot \Delta u
\end{gathered}
$$

ここに, $t$ は時間, $\Delta t$ は時間増分量, $\Delta u$ は要素 $i$ と $j$ 間の 相対速度, $k$ は弾性係数, $c$ は減衰係数, $L_{i j}^{0}, L_{i j}^{t}$ は要素 が接している状態, 時間 $t$ における要素中心間の距離で ある。

\section{h) 漂流物内の要素間力}

漂流物内における要素間力には軸方向の力の他に，漂 

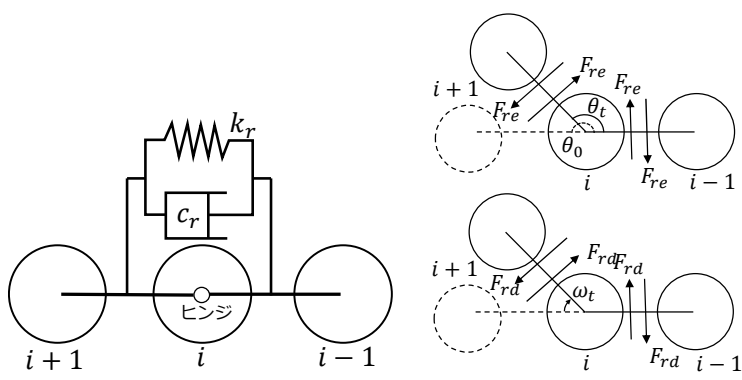

図-6 せん断変形モデルと変形により生じる力

流物のせん断変形に対する復元力として，せん断方向の 力を考慮する. せん断方向の力は，図-6 に示すバネ・ ダッシュポットヒンジモデル を用いて表現し，バネ力 $F_{r e}$ およびダッシュポットによる力 $F_{r d}$ の総和より求める.

$$
F_{r}=-\sum\left(F_{r e}+F_{r d}\right)
$$

また，せん断による力は，要素iおよび隣接する 2 つの 要素に加える. バネ力 $F_{r e}$ およびダッシュポットによる 力 $F_{r d}$ は, 要素iの位置での曲げ角と角速度を用いて, 次 式により算出する.

$$
\begin{gathered}
F_{r e}^{t+\Delta t}=k_{r} \cdot\left(\theta_{i}^{0}-\theta_{i}^{t}\right) \\
F_{r d}^{t+\Delta t}=c_{r} \cdot \omega_{\mathrm{i}}
\end{gathered}
$$

ここに, $\omega_{i}, \theta_{i}^{0}, \theta_{i}^{t}$ は要素ににおける曲げ速度, 初期曲げ 角, 時刻 $t$ における曲げ角, $k_{r}, c_{r}$ は曲げに対する弾性係 数と減衰係数, $\theta_{i}^{0}, \theta_{i}^{t}$ を示寸.

\section{3. 数値解析例}

\section{(1) 陸上遡上津波に対する建物周辺の漂流物の挙動}

本研究で開発したモデルの妥当性を検討寸ることを目 的として，基本的な水路に構造物がある場合の漂流物の 挙動解析を行った．対象とした水路は，図-7上図に示寸 とおり，段波が陸上を遡上して漂流物が構造物に衝突す るようなケースを設定した. 入射波は水位差 $8.0 \mathrm{~m}$ の段 波とした. 漂流物は $5 \mathrm{~m} \times 2.5 \mathrm{~m} \times 2.5 \mathrm{~m}$ の大きさとして半径 $0.625 \mathrm{~m}$, 高さ $2.5 \mathrm{~m}$ の個別要素8個で表現し, 遡上域に10 個配置した（図-7 下図）。漂流物はその比重の違いに より挙動の違いがあるため，本件検討では，特に建物周 辺での挙動を比較するために3種類の比重 $(0.1,0.5,0.9)$ を条件とした. 津波浸水解析の格子サイズは $2 \mathrm{~m}$ とて, 時間増分量は $\Delta t$ は $5 \times 10^{-6}$ 秒とした。

図-8に比重が0.5の場合における建物周辺における水 面形状と漂流物の挙動の時間変化を示寸. 複数の漂流物 は，津波の遡上により移動が始まり，構造物に衝突する. 衝突した漂流物は建物手前の水位のせり上がりと同時に, 浮き上がり回り込んでばらつきを持ちながら移動する. なお，構造物は2次元の数值シミュレーションでは地形 として表現しており, 従来に用いられている建物の影響

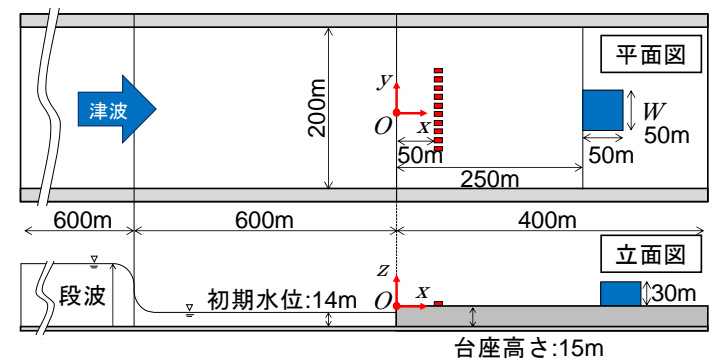

水路全体

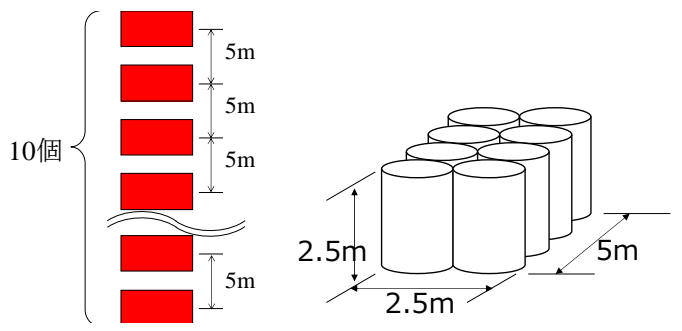

漂流物周辺

図-7 水路および漂流配置

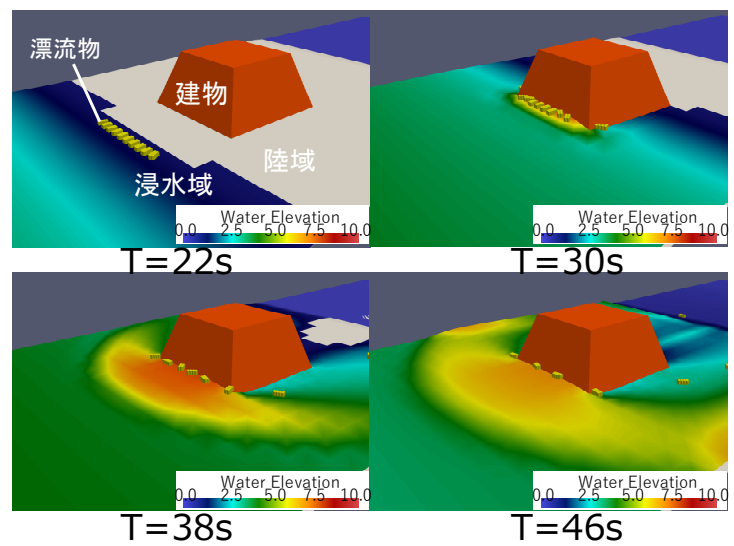

図-8＼cjkstart建物周辺における津波水位変化と漂流物の挙動

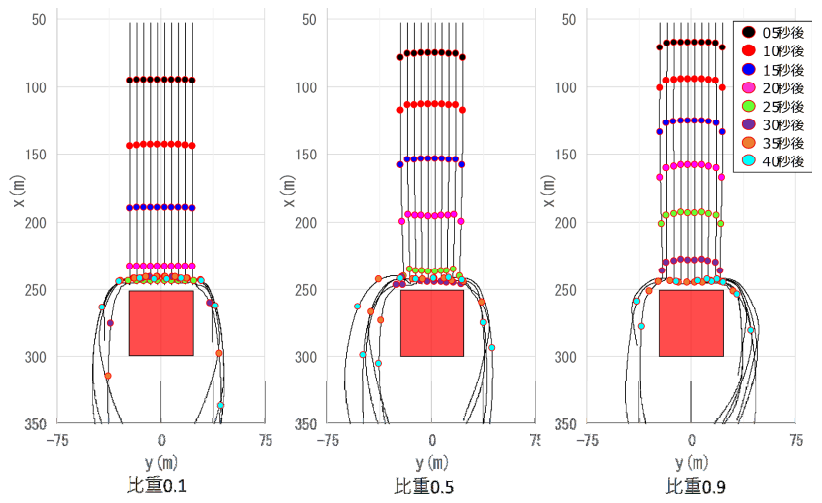

図-9＼cjkstart建物周辺における漂流物の軌跡

を考慮した津波シミュレーションの地形データを活用し ながら漂流物の移動過程を表現することができる，

図-9に建物周辺における漂流物の軌跡を示す。この図 より，漂流物が建物に衝突して広がることが見てとれる. また，比重が 0.1 と0.9の場合を比較すると，比重 0.9 の場 合は漂流物がスパン方向・流軸方向にやや広がりながら 流下寸る.この傾向は，既往の実験8) と同等の傾向であ る. また，全ての比重の条件でも構造物に衝突してから， 


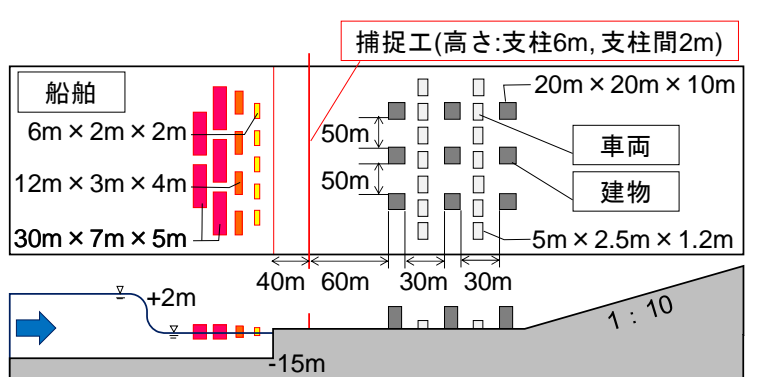

水路全体

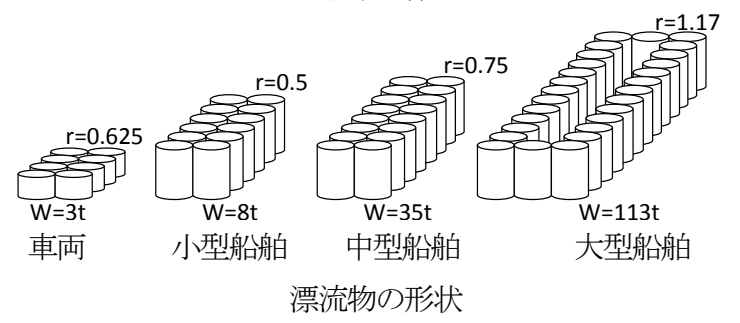

図-10＼cjkstart水路および漂流物配置

不確定性な挙動により回り込む傾向となった.

\section{(2) 多種・多数の漂流物の挙動検討}

次に現地スケールへの適用性を評価するために，複数 の種類（船舶，車両）の漂流物と津波捕捉工・建物の影 響を含めた計算を行った．水路および漂流物の配置は図 -10に示すとおりであり，車両，船舶（大型，中型，小 型）を対象として捕捉工の有無の両方を比較した. 入射 波は段波として，水位差 $2 \mathrm{~m}$ とた。陸域には立方体の 建物を配置して，その中に車両を複数台配置した．海域 では，大型，中型，小型船舶を配置した，それぞれの漂 流物の形状，大きさは実際の大きさを仮定し，図-10の 下図のようにした．漂流物捕捉工は漂流物と同様に円柱 の個別要素によりモデル化を行い，漂流物との衝突を考 慮できるようにした．支柱の高さは $6 \mathrm{~m}$ ，支柱間高さは2 $\mathrm{m}$ とした. 津波浸水計算の格子サイズは $2 \mathrm{~m}$, 時間増分量

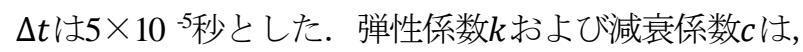
それぞれ $5 \times 10^{+9} ， 5 \times 10^{+4}$ を用いた．回転に関するバネ 定数 $k_{r}$ および咸衰定数 $c_{r}$ は， $1 \times 10^{+10}, 1 \times 10^{+9}$ 用いた。 図-11に捕捉工を設置しない場合における各時刻（5秒後, 8秒後，30秒後）の漂流物の移動状況を示寸．ここで5, 8 秒後は押し波，30秒後は引き波による状況である。この 結果より，押し波で多くの漂流物が遡上して，遡上先端 に多くの漂流物が滞留することがわかる．大型船舶は建 物手前で捕捉されるものが多いが，一部は建物をすり抜 けていることもわかる. また，引き波では遡上先端に各 種の漂流物が残ると同時に，多くの大型船舶が沖に戻る ことがわかる．この傾向を比較するために著者らが質点 系の運動により計算した方法による結果 ${ }^{2}$ と比較した.

図-12に同じ時間帯による漂流物の移動状況を示す８秒 後（押し波）による結果を比較すると，本手法は漂流物 の形状や建物や漂流物同士の衝突を考慮した計算である

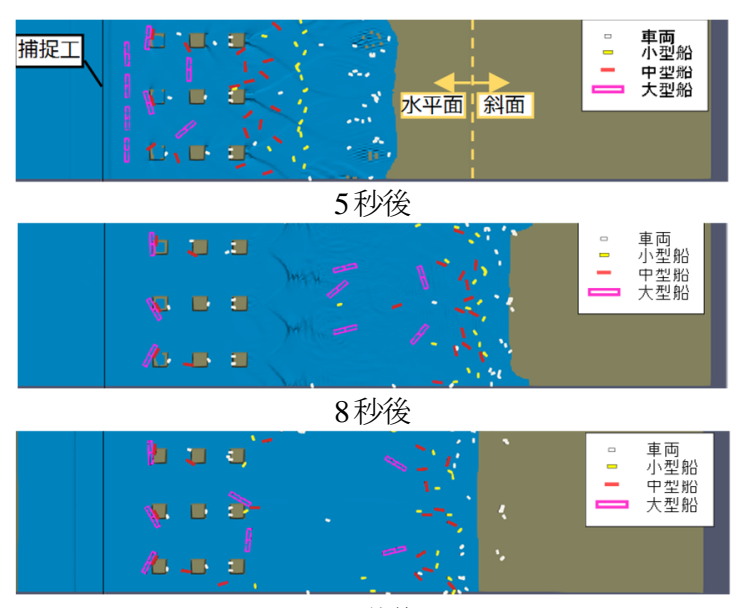

30 秒後

図-11 各時刻における漂流物の挙動（捕捉工なし）

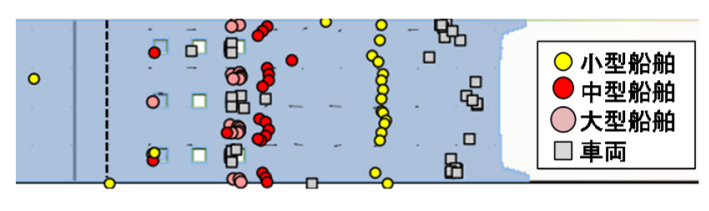

8 秒後

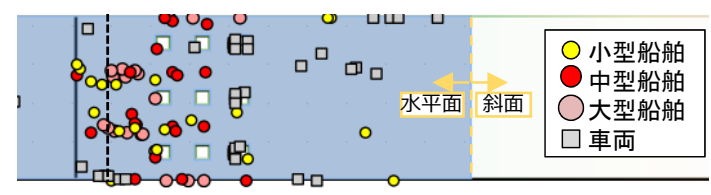

30 秒後

図-12 既往研究による計算結果 ${ }^{2}$

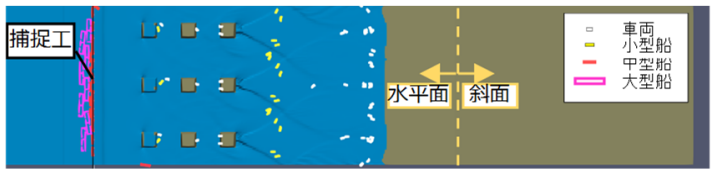

5 秒後

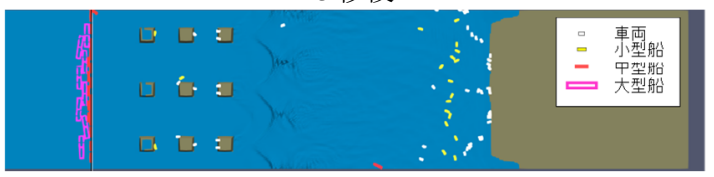

8 秒後

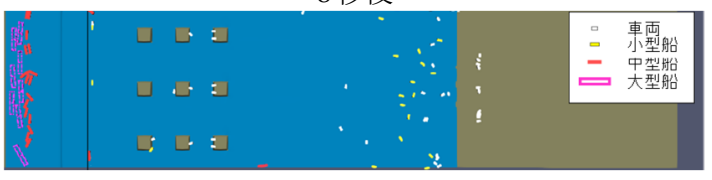

30 秒後

図-13 各時刻における漂流物の挙動（捕捉工あり）

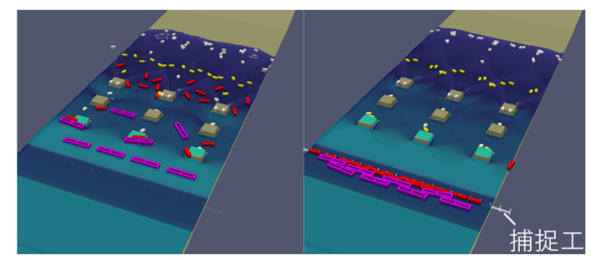

捕捉工なし

捕捉工あり

図-145秒後における漂流物の状況（鳥㒈図）

ことから，特に大型船舶では，建物手前で滞留しており， 既往の結果との差異が見られる. 既往の計算結果は漂流 物形状を定数で表現しており，全体的に押し波で押され 
る状況になる．なお，小型船舶や車両はいずれの結果も 遡上先端に近いところで漂流するが，本手法の方がその 影響が顕著である.これは，遡上先端付近で摩擦の影響 を受けながら遡上・停止を繰り返したためであると考え られる. 既往の計算は，摩擦の影響を考慮していないた め, 一定の水深条件で漂流停止となり, 本手法とは挙動 が異なる，一方，引き波の結果を比較すると，本手法に よる結果は, 遡上域に全体的に滞留する. これは, 押し 波と同様に遡上先端付近で摩擦の影響を受けた後, 引き 波により移動したものである．また，大型船舶は本手法 による計算結果は縦横の形状を考慮した影響により流体 力が様々な方向を受けるケースがあるため, 沖に戻るも のと遡上域に滞留するものに分かれる. 既往の手法は,

一律の形状であることから，ほぼすべての漂流物が沖に 戻る傾向となる.

図-13に捕捉工がある場合の漂流物の平面分布状況を 示す．捕捉工がある場合は，大型・中型船舶の多くは捕 捉工により捕捉され引き波で沖合に流されている.この モデルは津波捕捉工も物理的に考慮しているため, 従来 のように捕捉工の通過条件を強制的に考慮するようなも のでなく，限りなく物理過程に忠実に表現できるように なっている. 図-14に建物および捕捉工周辺の津波と漂 流物の挙動の鳥㒈図を示す。この結果より, 建物の側面 や上面にも漂流物が捕捉されるような3次元的な挙動が 考慮できることも確認できる.

\section{4. おわりに}

従来の平面2次元の津波シミュレーションを用い，流 体と漂流物の力の相互干渉を考慮した漂流物シミュレー ションのモデルを開発した. 開発したモデルは漂流物・ 構造物間の衝突，遡上等の影響を評価することが可能と なっており, その妥当性を示寸ために構造物周辺での漂 流物の移動軌跡の検証, 多種・多数の漂流物に対する構 造物への影響を考察した. その結果, 以下の結論が得ら れた.
- 単体の建物周辺における漂流物の移動に対して, 本研究で開発したモデルを適用した結果，漂流物 の比重の違いによる影響を表現した。また，建物 を回り込む特性の違いについても傾向を捉えるこ とが可能となった。

- 複数の規模の船舶, 車両が建物や津波捕捉工に対 する影響を踏まえた漂流物シミュレーションを行 つた結果, 建物や漂流物同士の衝突, 座礁, 乗り 上げなどの現象を再現した．また，津波捕捉工の 影響も物理的に再現することが可能となった.

今後の課題として, 個々のもつ漂流物の衝突確率や衝 突力の評価について検証することが挙げられる

\section{参考文献}

1) 水産庁漁港漁場整備部：漁港の津波漂流物対策施設 設計ガイドライン (案) , 119p, 2016.

2)野島和也, 桜庭雅明, 小園裕司: 津波バリアの影響 を考慮した実務的な津波漂流物計算モデルの開発, 土木学会論文集 B2（海岸工学）, Vol.71,No.2, p I_283-I_288., 2015.

3) 後藤智明: 津波による木材の流出に関する計算, 第 30 回海岸工学講演会論文集, pp.594-597, 1983.

4) 橋本貴之, 越村俊一, 小林英一, 藤井直樹, 高尾 誠：津波来襲時における船舶漂流・座礁モデルを用 いた臨海都市域危険度マップの開発, 土木学会論文 集 B2（海岸工学）, Vol. 66, No.1, pp.236-240, 2010.

5) 鴫原良典, 許松, 多田毅: 津波漂流物モデルの現地 スケール問題への適用に関する考察, 土木学会論文 集 B2（海岸工学）, Vol.72, No.2, p.I_427-I_432, 2016.

6) 米山 望, 永島 弘士: 複雑な移動・回転を考慮した津 波漂流物の三次元数值解析手法の開発, 土木学会論 文集 B2（海岸工学）, Vol 65, No.1, P, 266-270, 2009.

7) 後藤智明, 小川由信 : Leap-Frog 法による津波の数值 計算法, 東北大学土木工学科資料, 52p, 1982.

8) 甲斐田秀樹, 木原直人, 陸上遡上津波中の漂流物挙 動に関する研究, 土木学会論文集 B2 (海岸工学), Vol.72,No.2, pp.I_1159-I_1164, 2016.

(2017.3.15 受付)

\title{
DEVELOPMENT OF A MODEL FOR THE TSUNAMI DRIFTS ANALYSIS CONSIDERING EFFECTS OF STRUCTURES AND TSUNAMI BARRIER
}

\author{
Kazuya NOJIMA, Masaaki SAKURABA and Yuji KOZONO
}

In this study, we developed the model for tsunami drifts analysis considering effects of structures such as buildings and tsunami barriers. The developed model can consider the interaction between tsunami drifts and tsunami propagation. The model can also be considered behavier of the tsunami drifts at a wide variety of situation and can be extended based on 2-dimensional tsunami simulation model. As the example of application, we applied for a analysis of behavior of tsunami drifts around a building to estimate the validity of developed model and applied for a variety of tsunami drifts around structures. From these results, the deloveloped model can estimate a wide variety tsunami drifts behavior by using extended tsunami simulation model. 